\title{
WATER MOVEMENT IN CALCAREOUS SOIL UNDER TILLAGE, LEVELING AND BORDER IRRIGATION
}

\section{S. I. Abdel-Aal ${ }^{1}$ \\ ABSTRACT}

A field experiment was conducted at the Agricultural Experimental Station of the Desert Research Center, at Maryut, Alexandria Governorate. The main objective of the present work is optimizing of water movement and some soil physical properties in calcareous soil in respect to the effect of leveling methods (laser, traditional and noleveling), tillage depths $(15,20$ and $25 \mathrm{~cm})$, border irrigation length (25, 50 and $75 \mathrm{~m}$ ) and irrigation cut off after 80 and $90 \%$ of border length.

The obtained results can be summarized as follows:

The highest bulk density and penetration resistance increasing were 13.04 and $26.83 \%$ at $0-10 \mathrm{~cm}$ soil layer by using laser leveling and 15 $\mathrm{cm}$ tillage depth. Meanwhile, the lowest values were 1.42 and $5.35 \%$ at $20-30 \mathrm{~cm}$ soil layer by using traditional leveling and $15 \mathrm{~cm}$ tillage depth. The highest infiltration rate decreasing was $22.95 \%$ after using laser leveling and $15 \mathrm{~cm}$ tillage depth.

Data presented indicate that increasing the tillage depth from 15 to 20 and to $25 \mathrm{~cm}$, the advance time at $25 \mathrm{~m}$ border length when irrigation cut off after $90 \%$ of border length, increased from 8.8 to 10.7 and to 13.4 min; 9.4 to 10.8 and to $14.1 \mathrm{~min}$ and 9.2 to 11.2 and to 15.7 min under laser, traditional and no-land leveling respectively.

Data presented indicated that with laser land leveling and $20 \mathrm{~cm}$ tillage depth, the recession time when irrigation cut off after $90 \%$ of border length decreased by 14.29 and $38.84 \% ; 17.46$ and $41.75 \%$ and 20.16 and $37.39 \%$ under 25, 50 and $75 \mathrm{~m}$ border lengths compared to traditional and no-land leveling respectively.

Data presented indicated that increasing the border length from 25 to 50 and to $75 \mathrm{~m}$, the opportunity time at $20 \mathrm{~cm}$ tillage depth when irrigation cut off after $90 \%$ of border length, increased from 31.5 to 39.4 and to

\footnotetext{
${ }^{1}$ Assoc. Prof. of Agric. Eng. Dept., Fac. of Agric., Zagazig Un.
} 
$47.8 \mathrm{~min} ; 49.1$ to 61.1 and to $71.7 \mathrm{~min}$ and 65.2 to 77.8 and to $82.9 \mathrm{~min}$ under laser, traditional and no-land leveling respectively.

\section{INTRODUCTION}

eclamation of desert soil is one of the main principles of Egypt's
strategy to face down the agricultural demands of over
increasing population. Fifty percent of the newly reclaimed areas are calcareous soil in nature and about 3 million feddan calcareous soil are under reclamation (El-Bagouri, 1994). The main problem in calcareous soil is high calcium carbonate content, which affect distinctly soil properties and hence crop production. Improvement of that soil depends mainly on two important processes, improvement of soil structure and irrigation management (El-Sersawy, 1989).

Micheal (1990) found that leveling operation significantly increased the soil bulk density at the surface layer. This increment could be attributed to the effect of land leveling on breaking, loosening and compacting of soil particles. Also, it is evident that the change in soil bulk density was higher at the surface layer of $0-10 \mathrm{~cm}$.

Yousef (1991) found that the values of bulk density after using laser leveling and traditional leveling methods were higher in the bottom layer of $20-30 \mathrm{~cm}$ than the upper layer of $10-20$ and $0-10 \mathrm{~cm}$. The difference in bulk density values between laser and traditional leveling were 23.68, 9.16 and $8.27 \%$ at the $0-10,10-20$ and $20-30 \mathrm{~cm}$ layers, respectively.

Abdel-Maksoud et al. (1993) found that the increasing in penetration resistance were $18.5 \%$ using traditional leveling compared with $41.5 \%$ laser leveling.

Ibrahima et al. (1995) found that ploughing increased infiltration by $20 \%$ resulting in faster and greater water recharge in the root zone.

Abd El-Hafez el al. (1996) found that advance and recession time for irrigation water increased under traditional land leveling compared with zero level and $0.2 \%$ slope land leveling. They found that infiltration rate and cumulative infiltration decreased for initial, traditional, zero level and $0.2 \%$ slope land leveling. They found that opportunity time and calculated infiltration depth increased under traditional land leveling compared with zero level and $0.2 \%$ slope land leveling. They found that 
bulk density for 0-60 $\mathrm{cm}$ depth increased for initial, traditional, zero level and $0.2 \%$ slope land leveling.

El-Sherbeny et al. (1997) found that by increasing furrow irrigation lengths from 15 to $45 \mathrm{~m}$, the water application efficiency decreased from 90.2 to $85.9 \%$, respectively.

El-Saadawy and Abd El-Latif (1998) found that increasing the border length from 50 to $100 \mathrm{~m}$, the water application efficiency decreased from 62.84 to $51.64 \%$ and 90.9 to $73.89 \%$ for traditional method of land leveling and slope of about $0.1 \%$ respectively in silt clay soil.

El-Saadawy and Mohamed (1998) indicated that the irrigation water amount increased under deep plowing $(0-60 \mathrm{~cm})$ as compared by surface ploughing $(0-20 \mathrm{~cm})$. They added that furrow length of $25 \mathrm{~m}$ achieved the highest values of water use efficiency followed by $50 \mathrm{~m}$ furrow length, while the lowest value was obtained by $100 \mathrm{~m}$ furrow length.

El-Saadawey (2000) showed that water application efficiency for $0.04 \%$ slope with flow rates of $3 \mathrm{lit} / \mathrm{s}$ at furrow irrigation water in with $80 \%$ and $90 \%$ shut off were 76.9 and $79.1 \%$ comparing by 55.3 and $51.9 \%$, for traditional method respectively.

El-Yazal et al. (2002) found that the total advance time, water recession time, infiltration opportunity time and water applied decreased with ratios of $67.6,29.7,18.7$ and $21.33 \%$ under $0.1 \%$ slope compared with traditional irrigation method in clay soil.

Awad and Gomaa (2004) found that the application efficiency under laser leveling increased by $29.75,27.36$ and $17.17 \%$ under 50,100 and $150 \mathrm{~m}$ furrow length compared with traditional leveling.

Hashish et al. (2004) found that the advance time increased by increasing border length for traditional irrigation method. They found that the maximum water application efficiency was achieved in the case of 50 and 75 meter border length for irrigation with gated pipe system due to increased total water consumptive use in the other treatment and also increased water irrigation losses by runoff, deep percolation and evaporation. 
Khodeir (2011) found that the use of traditional land leveling gave the minimum values of bulk density and soil penetration resistance of 1.19 $\mathrm{kg} / \mathrm{m}^{3}$ and $4.79 \mathrm{~kg} / \mathrm{cm}^{2}$ respectively.

The objective of this research trial is to study surface irrigation performance through using border irrigation under different tillage depth, precision land leveling and suitable border length in calcareous soil. The effect of applying such methods on some soil physical characteristics, advance time, recession time and opportunity time were also investigated.

\section{MATERIALS AND METHODS}

\section{Field experiment}

The experiments were carried out at Agricultural Experimental Station of the Desert Research Center, at Maryut, (مريوط) Alexandria Governorate. The main objective of present work is to study the effect of tillage depths, land leveling methods and border lengths on some soil physical properties (bulk density, porosity and penetration resistances), advance time, recession time and opportunity time in calcareous soil. Table (1) shows some physical and chemical properties of the experimental soil.

Table1: Some physical and chemical properties of the experimental soil

\begin{tabular}{|c|c|c|c|c|c|c|c|c|c|c|}
\hline \multicolumn{3}{|c|}{$\begin{array}{c}\text { Particle size } \\
\text { distribution \% }\end{array}$} & \multirow{2}{*}{ 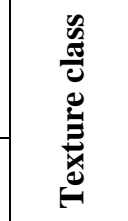 } & \multirow{2}{*}{$\dot{\theta}_{0}^{\infty}$} & \multirow{2}{*}{ نे } & \multirow{2}{*}{$\begin{array}{l}0 \\
0 \\
3 \\
3\end{array}$} & \multirow{2}{*}{$\begin{array}{l}80 \\
3\end{array}$} & \multirow{2}{*}{ 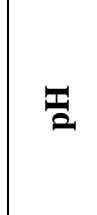 } & \multirow{2}{*}{ 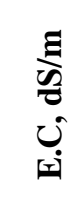 } & \multirow{2}{*}{$\sum_{0}^{0}$} \\
\hline Sand & Si & Clay & & & & & & & & \\
\hline 50.28 & 21.55 & 28.17 & S C L & 32.6 & 23.8 & 9.4 & 14.4 & 7.53 & 9.3 & 0.39 \\
\hline
\end{tabular}

SCL: Sandy clay loam, F.C, and W. P, by weight.

The variables of the present study may be summarized as follows:

1. Land leveling method: \{laser leveling at $0.05 \%$ slope, traditional leveling (tractor + scraper) and no-leveling $\}$.

2. Tillage depth: Three tillage depths $(15,20$ and $25 \mathrm{~cm})$.

3. Border irrigation length: Three border lengths $(25,50$ and $75 \mathrm{~m})$.

4. Irrigation water cut off after in the borders when water reached up to 80 and $90 \%$ of border length. 


\section{Materials:}

\section{Agricultural equipment:}

1. Unit of LASER control equipment: the laser control equipment in this work consists of the main parts as follows: transmitter (Model: 114, RPM: 300 cycle/minute, radius of light plane: $1000 \mathrm{ft}$ (300 m and power requirement: 12 Volts, DC, and 1.3 Ampere), receiver, control box, hydraulic mast and manual mast.

\section{Tractors:}

a- Massey Ferguson tractor of MF 399 model, made in England, four cylinders, diesel engine, four strokes, $76.44 \mathrm{~kW}, 4 \mathrm{WD}$ and water cooling.

b- Ford tractor, made in USA, 6610 model, four cylinders, diesel engine, four strokes, $53.4 \mathrm{~kW}, 2 \mathrm{WD}$ and water cooling.

\section{Land levelers:}

a- Laser leveler, local by manufactured with two wheels, $4.2 \mathrm{~m}$ working width and $2.69 \mathrm{~m}^{3}$ capacity and $5.2 \mathrm{~km} / \mathrm{h}$ forward working speed,

b- Traditional leveler, local by manufactured with two wheels, $3 \mathrm{~m}$ working width, $1.26 \mathrm{~m}^{3}$ capacity and $4.5 \mathrm{~km} / \mathrm{h}$ forward working speed.

\section{Chisel plough:}

Mounted chisel plough of 7 shanks with 1.75 m width.

The experimental design was in spilt-split plot, where land leveling was considered as the main treatment plot. The tillage depth was assigned as sub plots. The border length and irrigation water stopped in the borders were taken as the sub-sub plots and the plot area was divided into $3 \times 25$, $3 \times 50$ and $3 \times 75 \mathrm{~m}$. Each treatment was replicated three times.

The ploughing operation was performed for three depths of 15, 20 and 25 $\mathrm{cm}$ at soil optimum moisture content $16.7,19.2$ and $23.1 \%$ at $0-10,10-20$ and 20-30 cm soil layers. The equipment speeds were in the range of 2.8 $\mathrm{km} / \mathrm{h}$ for ploughing by chisel plough, $4.5 \mathrm{~km} / \mathrm{h}$ for traditional hydraulic leveler and $5.2 \mathrm{~km} / \mathrm{h}$ for laser land leveling at slope of $0.05 \%$.

\section{Measuring and instruments:}

a) Penetrometer: Japanese soil penetrometer model (SR-2, DIK-5500) was used in the present work. 
b) Infiltration rate: Average Infiltration rate was determined in the field using a local double ring 30 and $60 \mathrm{~cm}$ diameter.

c) Soil physical characteristics:

1- Soil bulk density: The soil samples were determined at three depths of $0-10,10-20$ and $20-30 \mathrm{~cm}$ to determine soil bulk density $\left(\mathrm{B}_{\mathrm{d}}\right)$ values before and after leveling according to Black (1965).

$$
\mathrm{B}_{\mathrm{d}}=\mathrm{M}_{\mathrm{s}} / \mathrm{V}_{\mathrm{t}}
$$

Where:

$$
\mathrm{M}_{\mathrm{s}} \text { : Dry soil mass, } \mathrm{g} \text { and } \mathrm{V}_{\mathrm{t}} \text { : Total soil volume, } \mathrm{cm}^{3}
$$

- Relative increase of bulk density $\left(\right.$ RIB $\left._{d}\right)$ : The relative increase of soil bulk density was calculated as follows:

$$
\mathbf{R I B}_{\mathbf{d}}=100\left(\mathrm{~B}_{\mathrm{d} 1}-\mathrm{B}_{\mathrm{d} 2}\right) / \mathrm{B}_{\mathrm{d} 1}
$$

Where:

$\mathrm{B}_{\mathrm{d} 1}$ and $\mathrm{B}_{\mathrm{d} 2}$ : Bulk density before and after treatments, $\mathrm{g} / \mathrm{cm}^{3}$

2- Soil particle density $\left(D_{s}\right)$ : The soil samples were determined at three depths of $0-10,10-20$ and $20-30 \mathrm{~cm}$ and to determine according to:

$$
\mathrm{D}_{\mathrm{s}}=\mathrm{M}_{\mathrm{s}} / \mathrm{V}_{\mathrm{s}}
$$

Where:

$\mathrm{V}_{\mathrm{s}}$ : Volume of soil solids, $\mathrm{cm}^{3}$.

3- Total soil porosity (E): Volume of pore space as the ratio to the total soil volume can be determined as the soil porosity by using the following formula:

$$
\mathbf{E}=100\left(1-\mathrm{B}_{\mathrm{d}} / \mathrm{D}_{\mathrm{s}}\right)
$$

- Relative increase of soil porosity (RIE): The relative increase of soil porosity percentage was calculated as follows:

$$
\mathbf{R I E}=100\left(\mathrm{E}_{1}-\mathrm{E}_{2}\right) / \mathrm{E}_{1}
$$

Where:

$\mathrm{E}_{1}$ and $\mathrm{E}_{2}$ : Soil porosity before and after treatments, $\%$.

4- Soil penetration resistance (RIPr): The reduction in the RIPr percentage was calculated from the following formula:

$$
\left(\mathbf{R I P}_{\mathbf{R}}\right)=\left\{\left(\mathrm{R}_{1}-\mathbf{R}_{2}\right) / \mathbf{R}_{1}\right\} 100
$$

Where:

$R_{1}$ and $R_{2}$ :Soil penetration resistance before and after operations, $N / \mathrm{cm}^{2}$ 


\section{d) Determination and measurements of irrigation water:}

\section{Rates of advance and recession of irrigation water:}

The irrigation run of each plot was divided into equal distances (stations) of $10 \mathrm{~m}$. Times of advance $\left(\mathrm{t}_{1}\right)$ and recession $\left(\mathrm{t}_{2}\right)$ of irrigation water were recorded at each station along the irrigation run.

\section{Opportunity time $\left(\mathbf{T}_{0}\right)$.}

$$
\mathbf{T}_{\mathbf{0}}=\mathrm{t}_{2}-\mathrm{t}_{1}
$$

3. Infiltration rate (I): was calculated by Kostiakov (1932):

$$
\mathbf{I}=\mathrm{C} \mathrm{T}^{\mathrm{n}}
$$

Where:

$\mathrm{C}, \mathrm{n}$ : Constants that depend on soil properties and

$\mathrm{T}$ : Time after infiltration started.

- Relative decrease of infiltration rate (PCI): Was calculated as follows:

$$
\mathrm{PCI}=100\left(\mathrm{I}_{1}-\mathrm{I}_{2}\right) / \mathrm{I}_{1}
$$

Where:

$\mathrm{I}_{1}$ and $\mathrm{I}_{2}$ : Infiltration rates before and after treatments, $\mathrm{cm} / \mathrm{h}$.

4. Water discharge: Concrete channel was established to determine water discharge $(\mathrm{Q})$ for each treatment as follows:

$$
\mathbf{Q}=\mathrm{A} . \mathrm{V}
$$

Where:

A: Cross section area of irrigation channel, $\mathrm{m}^{2}$ and

V: Irrigation water velocity in channel $(\mathrm{m} / \mathrm{sec})$ calculated using Manning equation:

$$
\mathrm{V}=1 / \mathrm{n} \times \mathrm{R}^{2 / 3} \times \mathrm{S}^{1 / 2}
$$

Where:

$\mathrm{n}$ : The roughness coefficient, 0.011 for concrete channel.

R: Hydraulic radius, $\mathrm{m}$, where $\mathrm{R}=\mathrm{A} / \mathrm{p} \quad \mathrm{S}$ : Channel slope.

A: Cross section of channel, $\mathrm{m}^{2}$ and $\mathrm{P}$ : Wetted perimeter, $\mathrm{m}$. 


\section{RESULTS AND DISCUSSION}

\section{Effect of land leveling method and tillage depth on some physical characteristics of calcareous soil.}

\section{a. Soil bulk density}

Data presented in Fig. (1) indicate that the soil bulk density in calcareous soil increased by increasing soil depth and land leveling, while it decreased by increasing tillage depth. The bulk densities were 1.21, 1.17 and $1.15 \mathrm{~g} / \mathrm{cm}^{3}$ at 15,20 and $25 \mathrm{~cm}$ tillage depths respectively at 10-20 $\mathrm{cm}$ soil layer in no-leveled. The highest soil bulk density value was $14.04 \%$ at upper soil layer of $0-10 \mathrm{~cm}$ using laser leveling and $15 \mathrm{~cm}$ tillage depth. Meanwhile, the lowest value was $1.42 \%$ at $20-30 \mathrm{~cm}$ soil layer using traditional leveling and $15 \mathrm{~cm}$ tillage depth. These results may be attributed to the compaction resulted from the heavy equipment of land leveling practice.

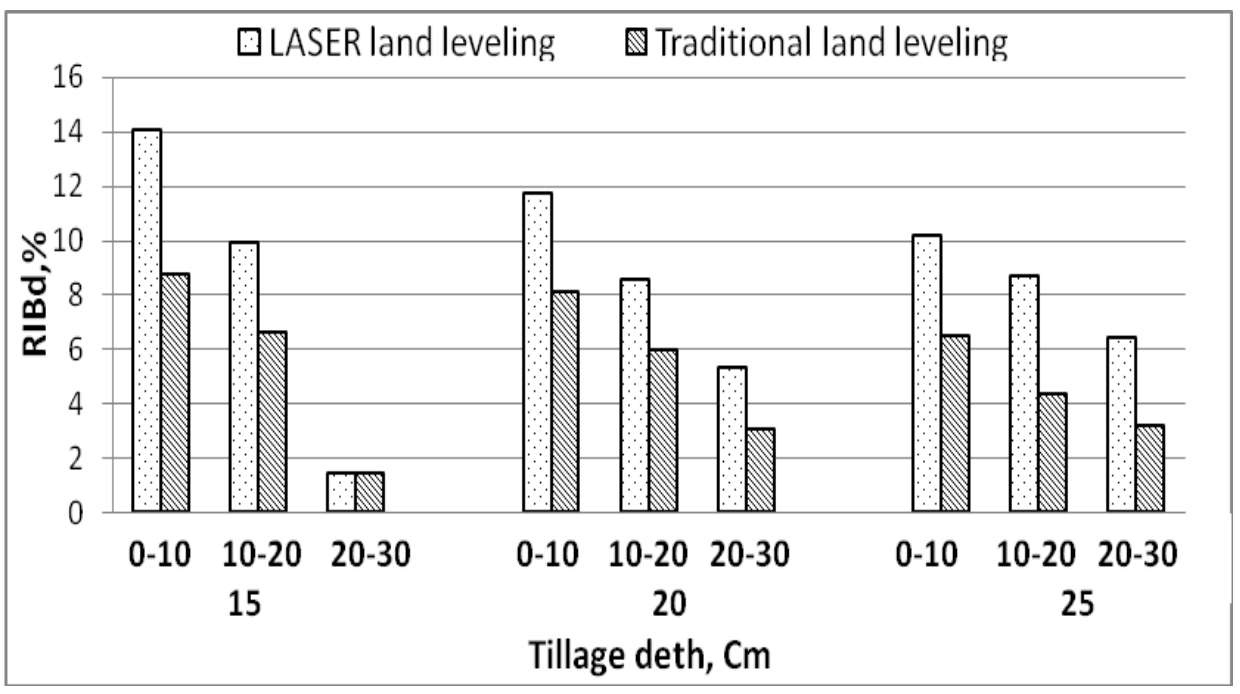

Fig. (1): Soil bulk density under different treatments.

\section{b. Soil porosity}

Data presented in Fig. (2) indicate that the total porosity decreased by increasing soil depth and land leveling, while it increased by increasing tillage depth. The total porosity at $20 \mathrm{~cm}$ tillage depth decreased from 55.47 to $53.21 \%$ and from 55.47 to $52.07 \%$ at $10-20 \mathrm{~cm}$ soil layer under 
traditional and laser leveling. Data presented in Fig. (2) indicate that increasing soil porosity value was $10.0 \%$ at upper soil layer of $0-10 \mathrm{~cm}$ by using laser leveling and $15 \mathrm{~cm}$ tillage depth. Meanwhile, the lowest value was $1.0 \%$ at $20-30 \mathrm{~cm}$ soil layer by using traditional leveling and

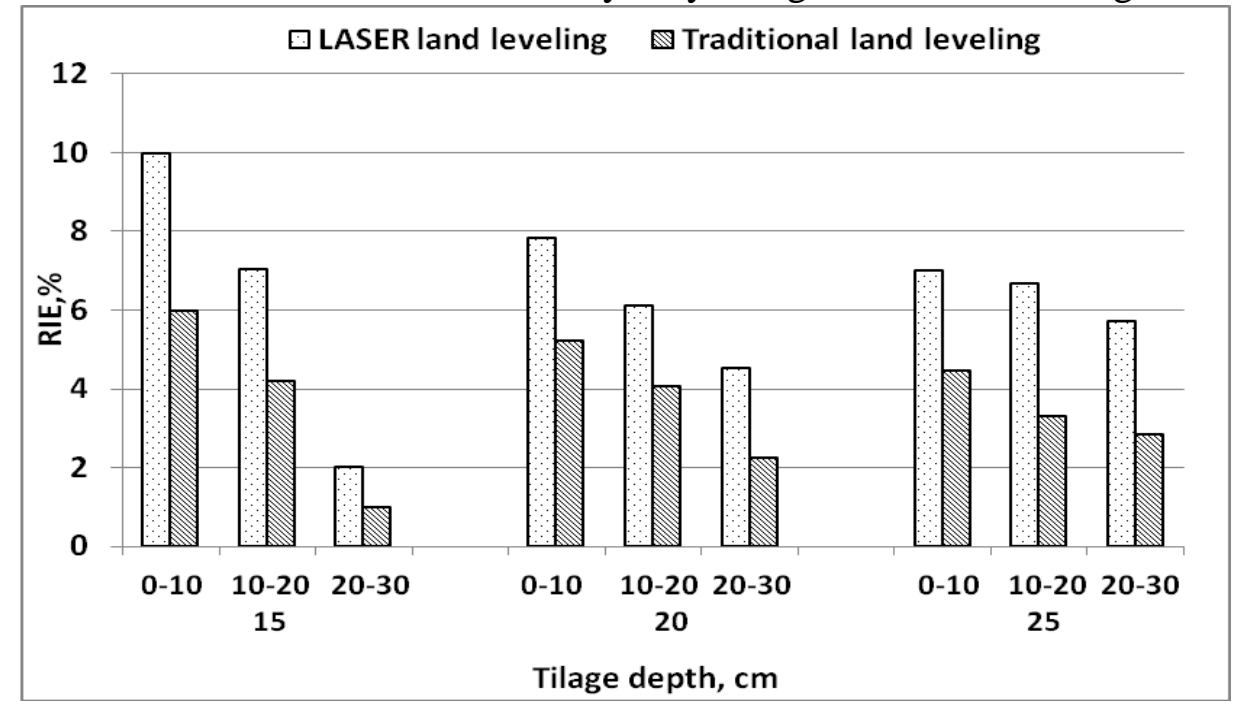

Fig.(2): Soil porosity in calcareous soil under different treatments.

$15 \mathrm{~cm}$ tillage depth. The highest soil porosity value was $59.24 \%$ under no-leveling and $25 \mathrm{~cm}$ tillage depth at $0-10 \mathrm{~cm}$ soil layer, while the lowest value was $46.60 \%$ by using laser land leveling and $15 \mathrm{~cm}$ tillage depth at $20-30 \mathrm{~cm}$ soil layer.

\section{c. Soil penetration resistance:}

Fig. (3) shows that soil penetration resistance increased by increasing soil depth and land leveling, while, it decreased by increasing tillage depth. The highest soil penetrations resistance value was $54.54 \mathrm{~N} / \mathrm{cm}^{2}$ by using laser land leveling, $15 \mathrm{~cm}$ tillage depth at $20-30 \mathrm{~cm}$ soil layer, while, the lowest value was $27.10 \mathrm{~N} / \mathrm{cm}^{2}$ under non-leveling and $25 \mathrm{~cm}$ tillage depth at $0-10 \mathrm{~cm}$ soil layer. The highest soil penetration resistance value increased by 26.83 and $17.64 \%$ under laser and traditional land leveling compared with no-leveling at $15 \mathrm{~cm}$ tillage depth at 0-10 $\mathrm{cm}$ soil layer. 


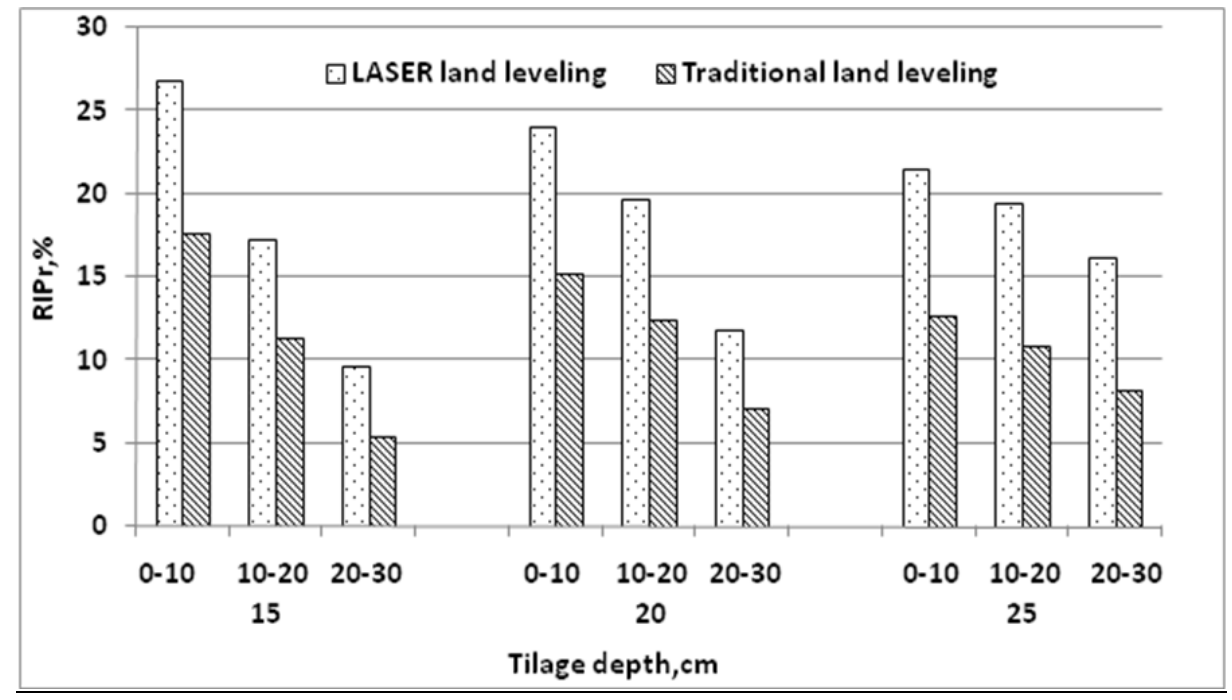

Fig. (3): Soil penetration resistance soil under different treatments

Meanwhile, the lowest values of the increasing were 9.63 and $5.35 \%$ at 20-30 cm soil layer.

\section{d. Infiltration rate:}

Data presented in Fig. (4) indicate that the infiltration rate increased by increasing tillage depth, while it decreased by using land leveling. The decreasing infiltration rate values were $22.87,19.48$ and $17.85 \%$ by using laser land leveling and $13.41,11.81$ and $10.64 \%$ by using traditional land leveling under 15, 20 and $25 \mathrm{~cm}$ tillage depth. These results may be due to the low accuracy of leveling operation in the case of unleveled and traditional leveling plots that required more quantities of water to reach up to the end of border, causing loss of water by infiltration through soil layers. However, using laser leveling in the calcareous soil improved the distribution of irrigation water and increased water advance time in the border, causing saving in irrigation water. 


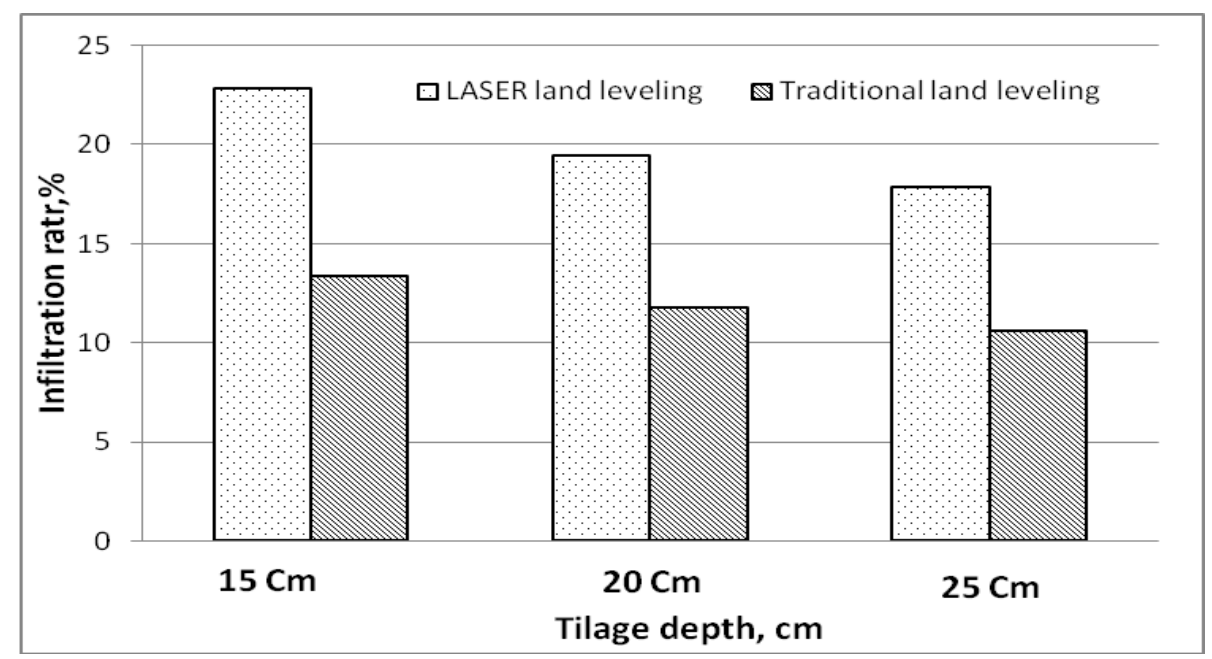

Fig.(4): Infiltration rate under different treatments.

\section{Effect of tillage depth, land leveling method and border length on water movement.}

\section{a. Advance time:}

Advance time in calcareous soil increased by increasing tillage depth and border length, while it decreased by using land leveling.

Data presented in Figs (5 to 7) indicate that increasing the tillage depth from 15 to 20 and to $25 \mathrm{~cm}$, the advance time at $25 \mathrm{~m}$ border irrigation length and irrigation cut off after $90 \%$ of border length, increased from 8.8 to 10.7 and to $13.4 \mathrm{~min} ; 9.4$ to 10.8 and to $14.1 \mathrm{~min}$ and 9.2 to 11.2 and to 15.7 min under laser, traditional and no-land leveling respectively. Data presented in Fig (5) indicate that increasing the border irrigation length from 25 to 50 and to $75 \mathrm{~m}$, the advance time at $15 \mathrm{~cm}$ tillage depth, increased from 7.7 to 10.2 and to $11.4 \mathrm{~min}$; 18 to 23.4 and to 32.8 $\mathrm{min}$; and 31.8 to 42.5 and to $52.2 \mathrm{~min}$ when irrigation cut off after $80 \%$ of border length and 8.8 to 10.7 and to $13.4 \mathrm{~min} ; 20.5$ to 23.4 and to 31.7 and 34.2 to 43.3 and to $51.7 \mathrm{~min}$ when irrigation cut off after $90 \%$ of border length under laser, traditional and no-land leveling respectively.

Data presented in Fig (6) indicate that at laser land leveling and $20 \mathrm{~cm}$ tillage depth, the advance time decreased by 21.35 and $57.30 \%$; 20.94 and $57.54 \%$ and 27.86 and $66.57 \%$ when irrigation cut off after $80 \%$ of 


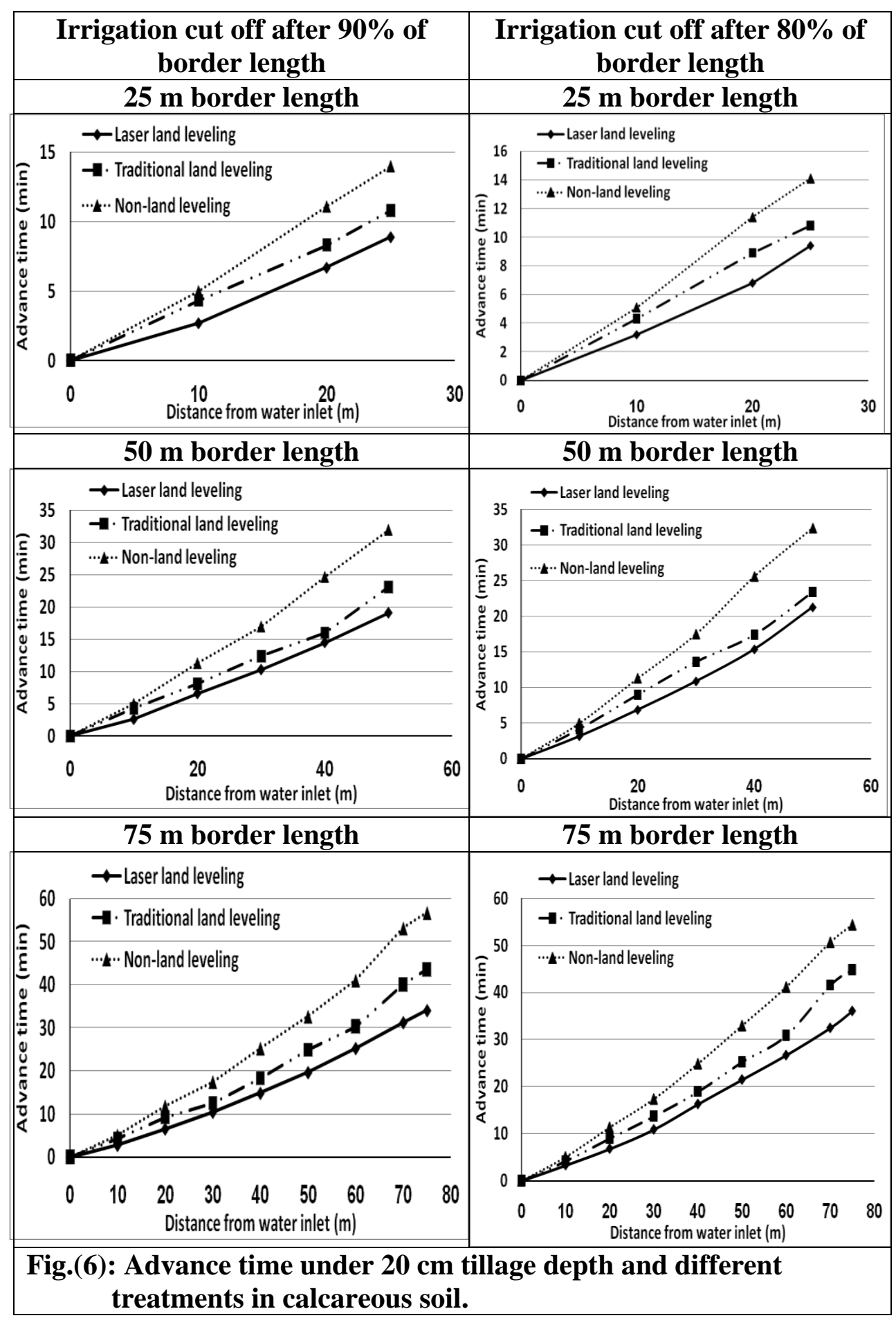


border length and 14.89 and 50.0\%; 9.86 and $52.11 \%$ and 24.10 and $50.69 \%$ when irrigation cut off after $90 \%$ of border length under 25,50 and $75 \mathrm{~m}$ border irrigation length compared to traditional and no-land leveling respectively, (Figs, 5 and 7 in appendix).

\section{b. Recession time:}

Recession time in calcareous soil increased by increasing border length, while, it decreased by using land leveling and increasing tillage depth.

Data presented in Figs ( 8 to 10) indicate that increasing the tillage depth 15 to 20 and to $25 \mathrm{~cm}$, the recession time at $25 \mathrm{~m}$ border irrigation length and irrigation cut off after $90 \%$ of border length, increased from 46.5 to 53.9 and to $64.9 \mathrm{~min} ; 44.8$ to 51.2 and to $62.2 \mathrm{~min}$ and 41.3 to 40.4 and to 58.9 min under laser, traditional and no-land leveling respectively.

Data presented in Fig (9) indicate that increasing border length of 25, 50 and $75 \mathrm{~m}$ at $20 \mathrm{~cm}$ tillage depth, the recession time decreased by 24.19 and $54.12 \% ; 23.46$ and $52.05 \%$ and 22.38 and $48.83 \%$ when irrigation cut off after $80 \%$ of border length, meanwhile, when irrigation cut off after $90 \%$ of border length were 14.29 and $38.84 \%$; 17.46 and $41.75 \%$ and 20.16 and $37.39 \%$ under laser land leveling compared with traditional and no-land leveling respectively (Figs, 8 and 10 in appendix).

\section{c. Opportunity time}

Opportunity time in calcareous soil decreased by increasing tillage depth and land leveling, while it increased by increasing border length.

Data presented in Figs (11 to 13) indicate that increasing the tillage depth 15 to 20 and to $25 \mathrm{~cm}$, the opportunity time at $25 \mathrm{~m}$ border irrigation length and irrigation cut off after $90 \%$ of border length, increased from 37.7 to 43.2 and to $51.5 \mathrm{~min} ; 58.3$ to 69.1 and to $76.7 \mathrm{~min}$ and 39.2 to 46.3 and to $57.0 \mathrm{~min}$ under laser, traditional and no-land leveling respectively.

Data presented in Fig. (12) indicate that at laser land leveling and $20 \mathrm{~cm}$ tillage depth, the opportunity time decreased by 25.08 and $51.75 \% ; 25.46$ and $46.0 \%$; 19.33 and $22.15 \%$ when irrigation cut off after $80 \%$ of border length and 13.83 and $35.88 \% ; 20.58$ and $38.27 \%$ and 17.84 and $30.14 \%$ when irrigation cut off after $90 \%$ of border length under 25,50 and $75 \mathrm{~m}$ border irrigation length compared to traditional and no- land leveling respectively, (Figs, 11 and 13 in appendix). 


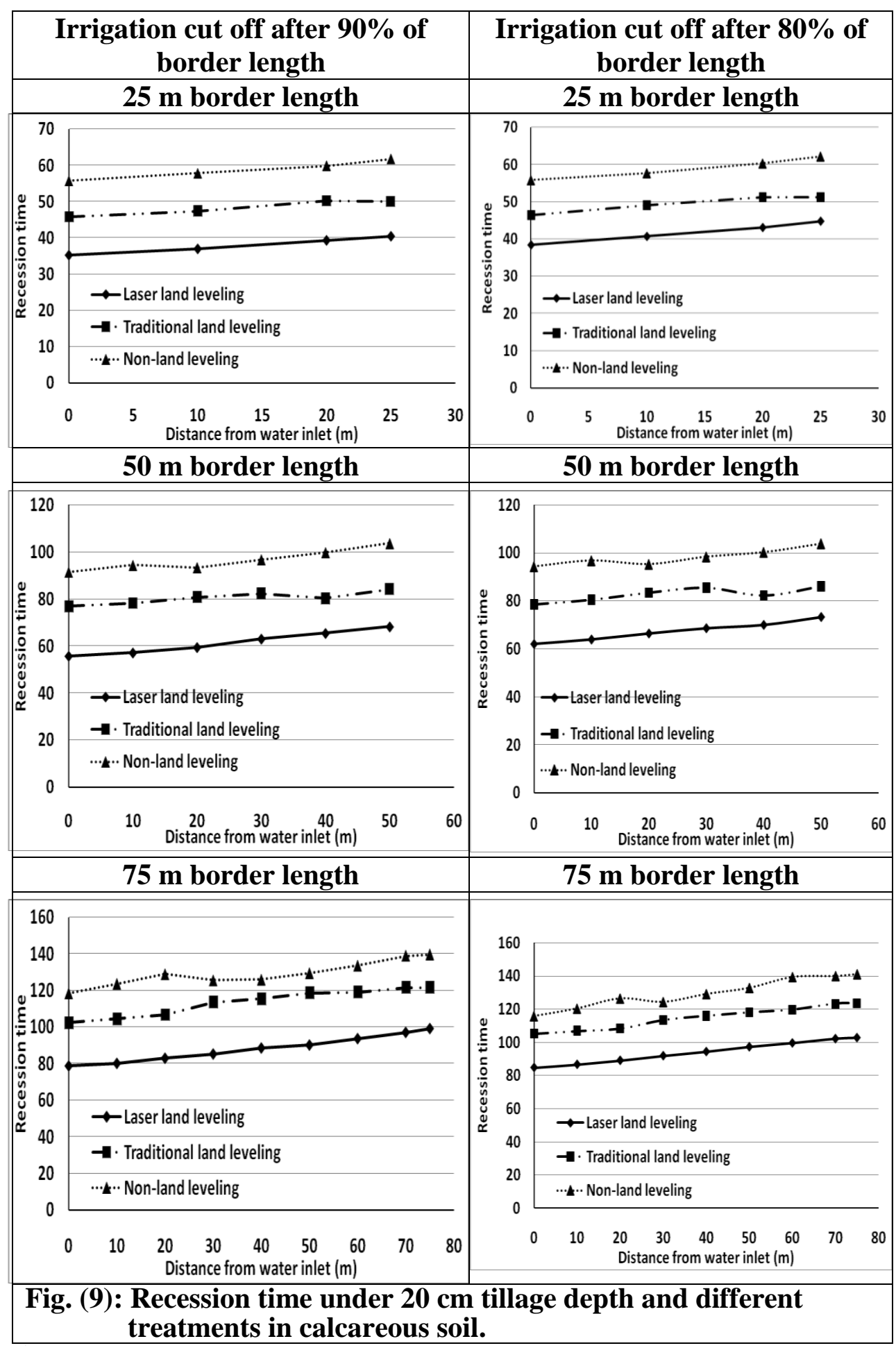

Misr J. Ag. Eng., April 2013 


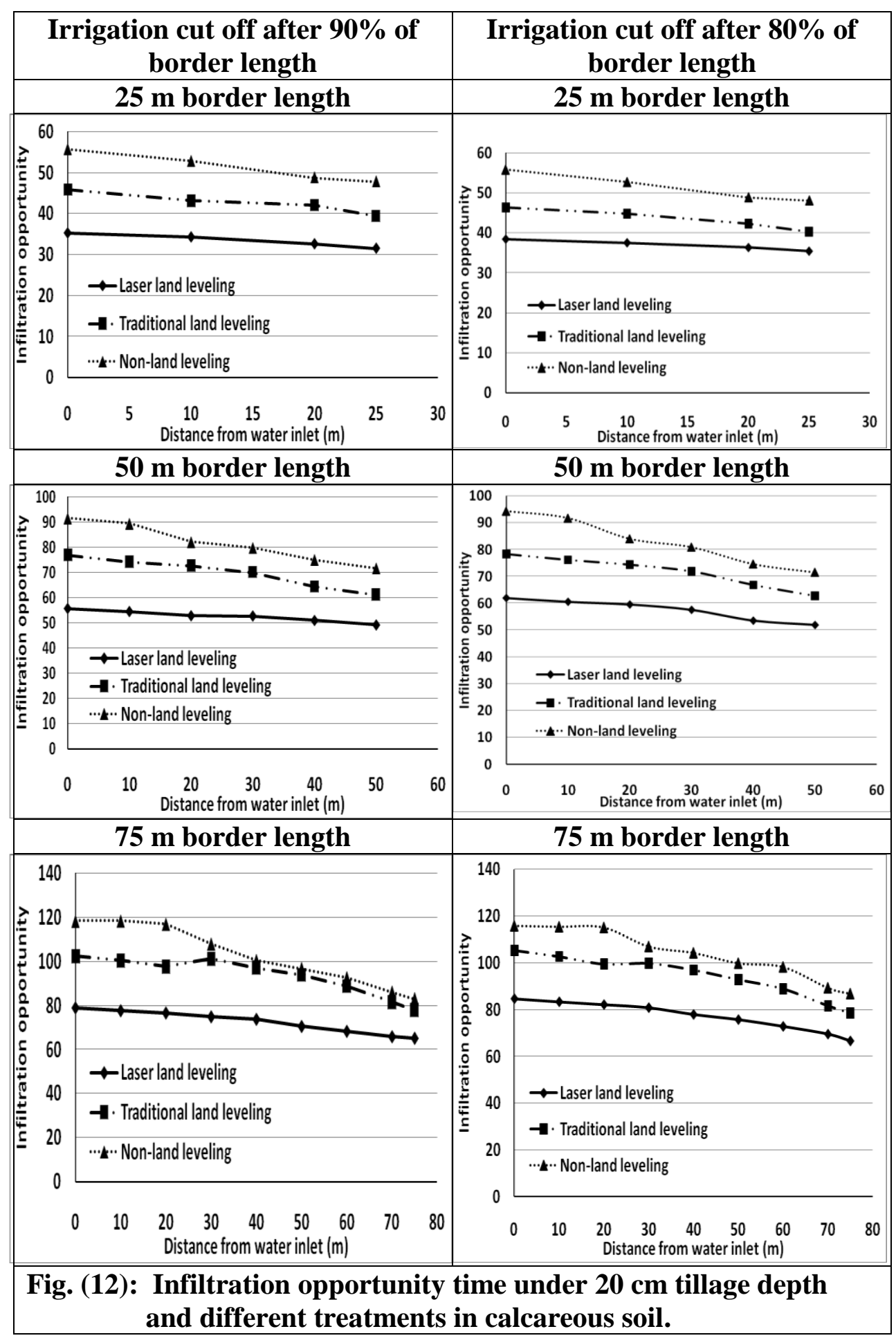




\section{The obtained results can be summarized as follows:}

1. The tillage depth of $20 \mathrm{~cm}$ and laser land leveling were considered the best conditions for calcareous soil as it improved soil physical properties (increasing soil bulk density, increasing the total porosity and decreasing soil penetration resistance).

2. The tillage depth of $20 \mathrm{~cm}$, laser land leveling, 25 border irrigation length and $90 \%$ of irrigation water stopped as the border length gave the best of water movement.

Finally, it could be concluded that, under the similar conditions:

The $20 \mathrm{~cm}$ tillage depth, laser land leveling, 25 border irrigation length and $90 \%$ of irrigation water stopped as the border length gave the improved soil physical properties and best of water movement (advance time, recession time, opportunity time and infiltration rate) under calcareous soil.

\section{REFERENCES}

Awad, M.A. and M.R. Gomaa (2004).Precision leveling effects on strip and furrow irrigations for maize. Misr Soc. Ag. Eng., 21(1):86-102.

Abdel-Hafez, S. A.; S. M. Hadidi, M. M. Said and M. S. Abo-Soliman (1996). Improving surface irrigation efficiency through land leveling management. Misr Sci. Ag. Eng., Cairo Univ. Irr. Conf., 235- 244.

Abdel-Maksoud, S.E.; A.E. Hashish; M.A. Hassan and S.F. Hassan (1993). A study on laser leveling technique as related to water use and yield. Misr J. Ag. Eng. 10 (4): 773-783.

Black, C. A. (1965). Method of soil and water analysis. Part 2:Madison, Wisc., USA.

El-Bagouri, I. H. (1994). Alternative farming systems for sustainable development of desert calcareous soil. Final Report NARP G.R., (54): c 2-3.

El-Saadawey M. A. (2000). Evaluation of some effective factors on surface irrigation. Misr. J. Agric. Eng., 17 (1): 248-254.

El-Saadawy A. M. and Z. Y. Abd El-Latif (1998). Rational application of water through land leveling. Misr J. Ag. Eng., 15 (2): 304 - 312. 
El-Saadawy, M. A. and A. A. E. Mohamed (1998). The effect of furrow length on water use efficiency of irrigated watermelon in new land. Misr J. Ag. Eng., 15 (3): 495-504.

El-Sersawy, M. M. (1989). A study on the physical properties and crust formation in calcareous soils. Ph. D. Thesis, Faculty. of Agric., Ain Shams Univ.

El-Sherbeny, A. M; M. I. H. Ward and A. A. El-Behery (1997). Evaluation of alternate irrigation technique under furrow irrigation system. Towards a national strategy for Ag. Eng; in Egypt for the next Decade $5^{\text {th }}$ conference of Misr society of Ag. Eng., $9^{\text {th }}$ September: 161-172.

El-Yazal, M. M.; S. S. Hassan and M. T. El-Tantawy (2002). Effect of land leveling on maize crop under perforated irrigation pipes in old land. Misr J. Agric. Eng., 19 (2): 437-454.

Hashich, A. I; S. S. Hassan; M. A. Matter and N. I. M. El-Nour (2004). Irrigation efficiencies of clover under different border lengths in upper Egypt. Misr J. Ag. Eng., 21 (2): 255- 272.

Ibrahima, A.,A. Mamoud and G. Vachaud (1995). Cultural techniques and water supply in the Sudano-Sahelian zone. CahiersAgricultures, 4 (1): 29- 38.

Khodeir, M.A. (2011). Effect of leveling methods on water requirements under different planting of rice methods. Misr J. Ag. Eng., 28 (4): 481- 498.

Kostiakov, A. N. (1932). On the dynamic of the coefficient of water percolation in soil and on the necessity of studying it from a dynamic point of view for purposes of amelioration. Trans. Com. Int. Soc. Soil Sci. $6^{\text {th }}$ Musco.

Michael, K. M. (1990). Effect of leveling on performance of some farm machinery. Ph. D. Thesis. Faculty of Agric., Moshtoher, Zagazig Univ.

Youssef, S. F. (1991). A study of precision land leveling by laser scraper in relation to water distribution and total yield. M. Sc. Thesis Faculty of Agric., Zagazig Univ. 
Appendix

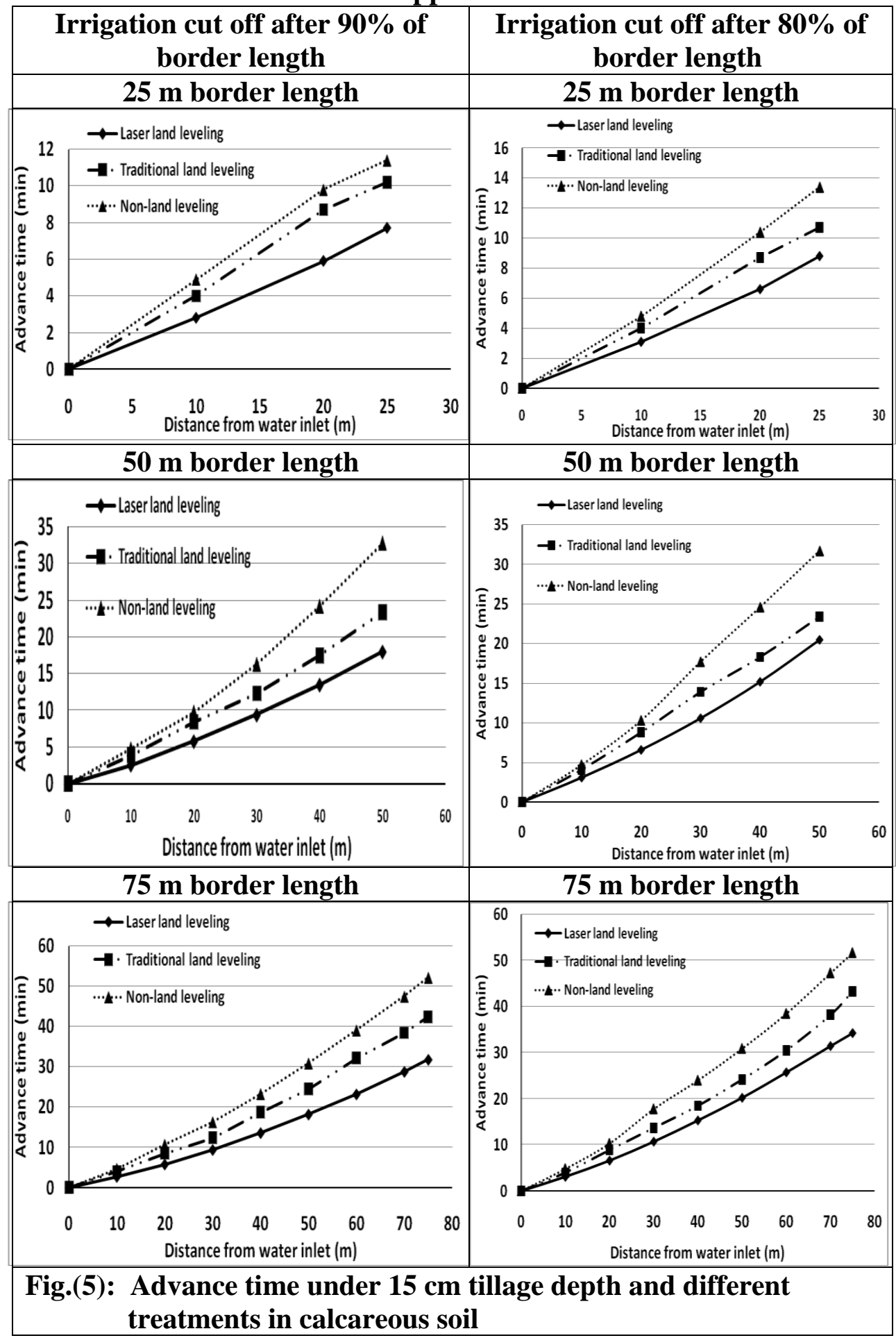




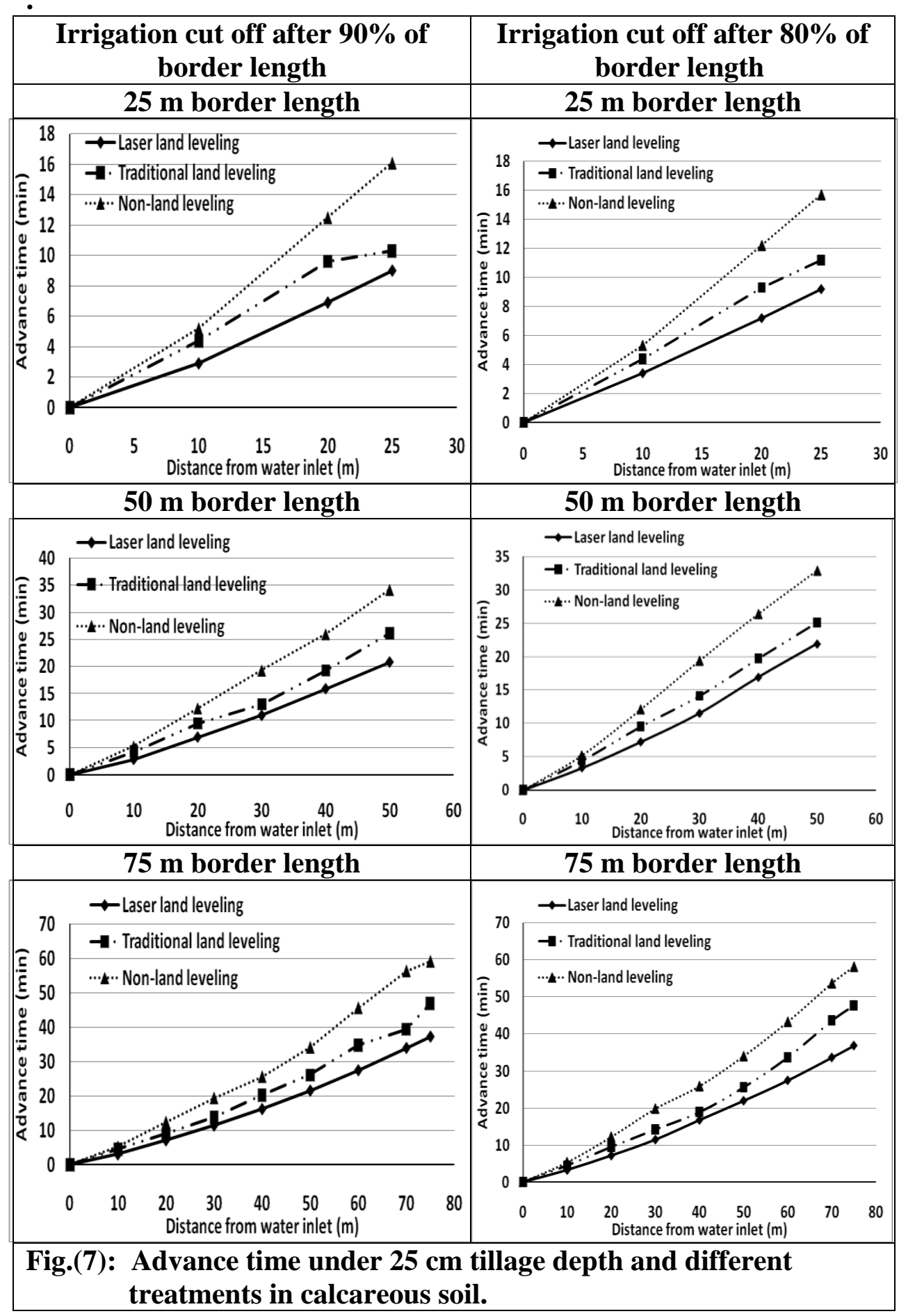




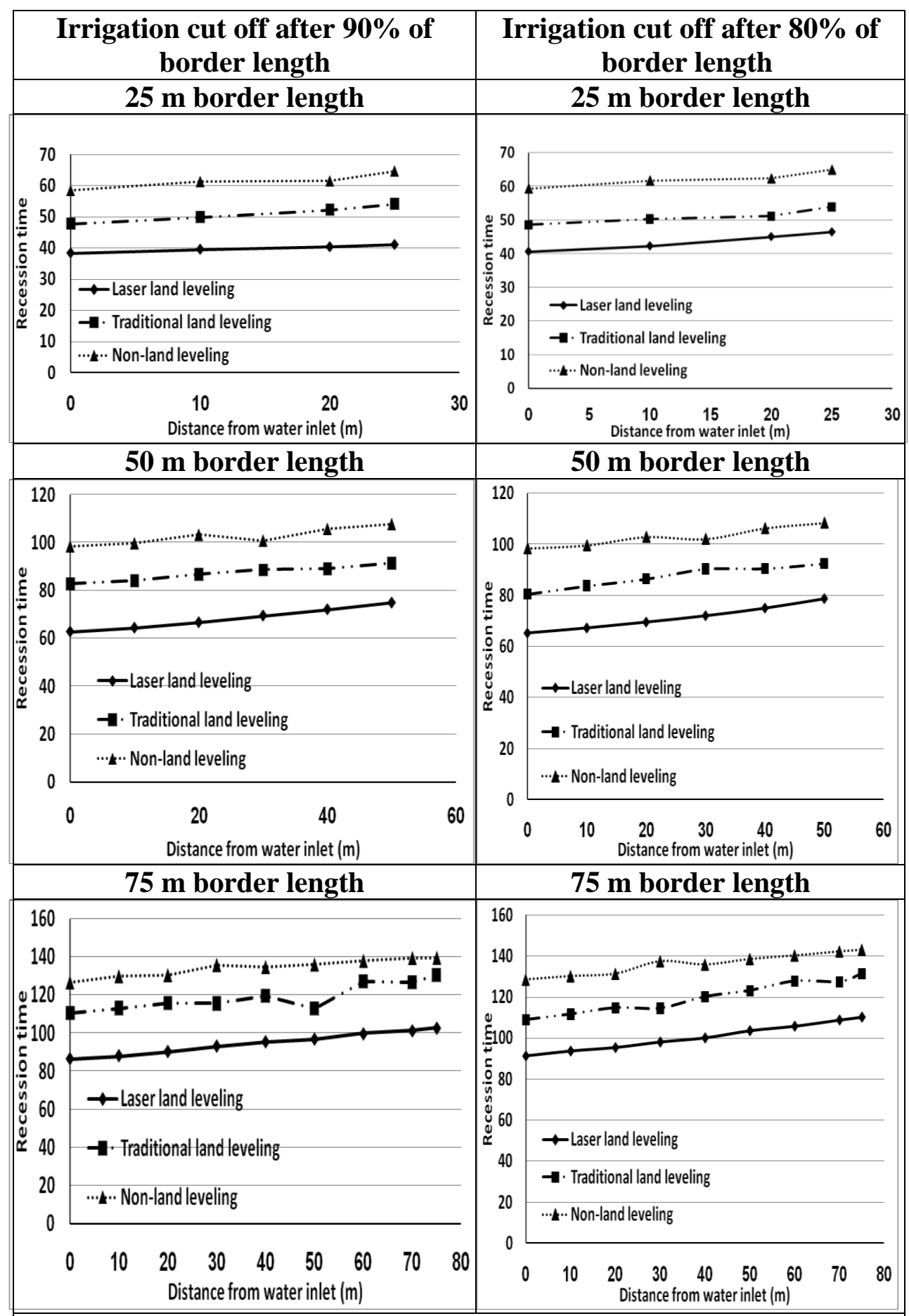

Fig. (8): Recession time under $15 \mathrm{~cm}$ tillage depth and different treatments in calcareous soil 


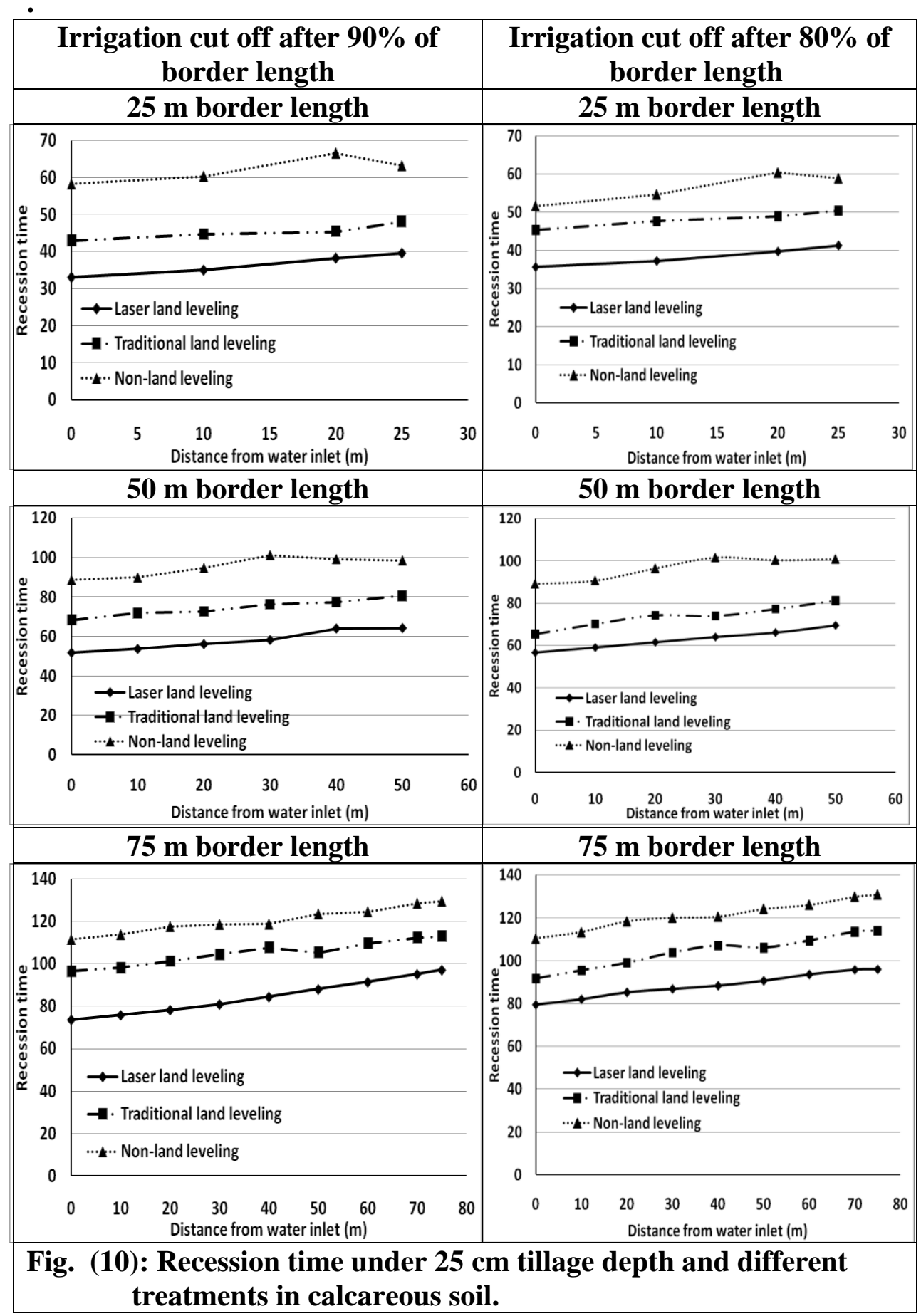




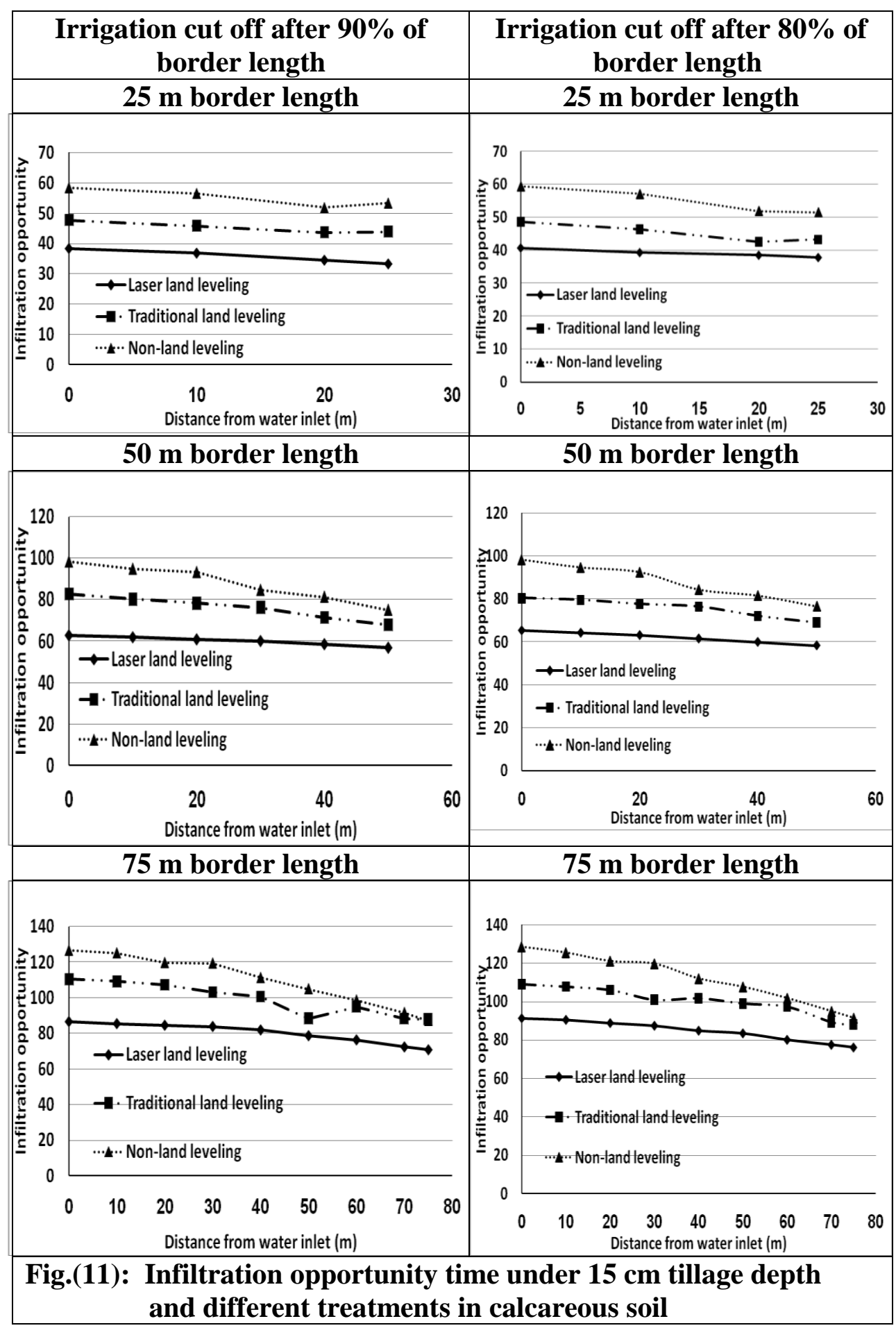




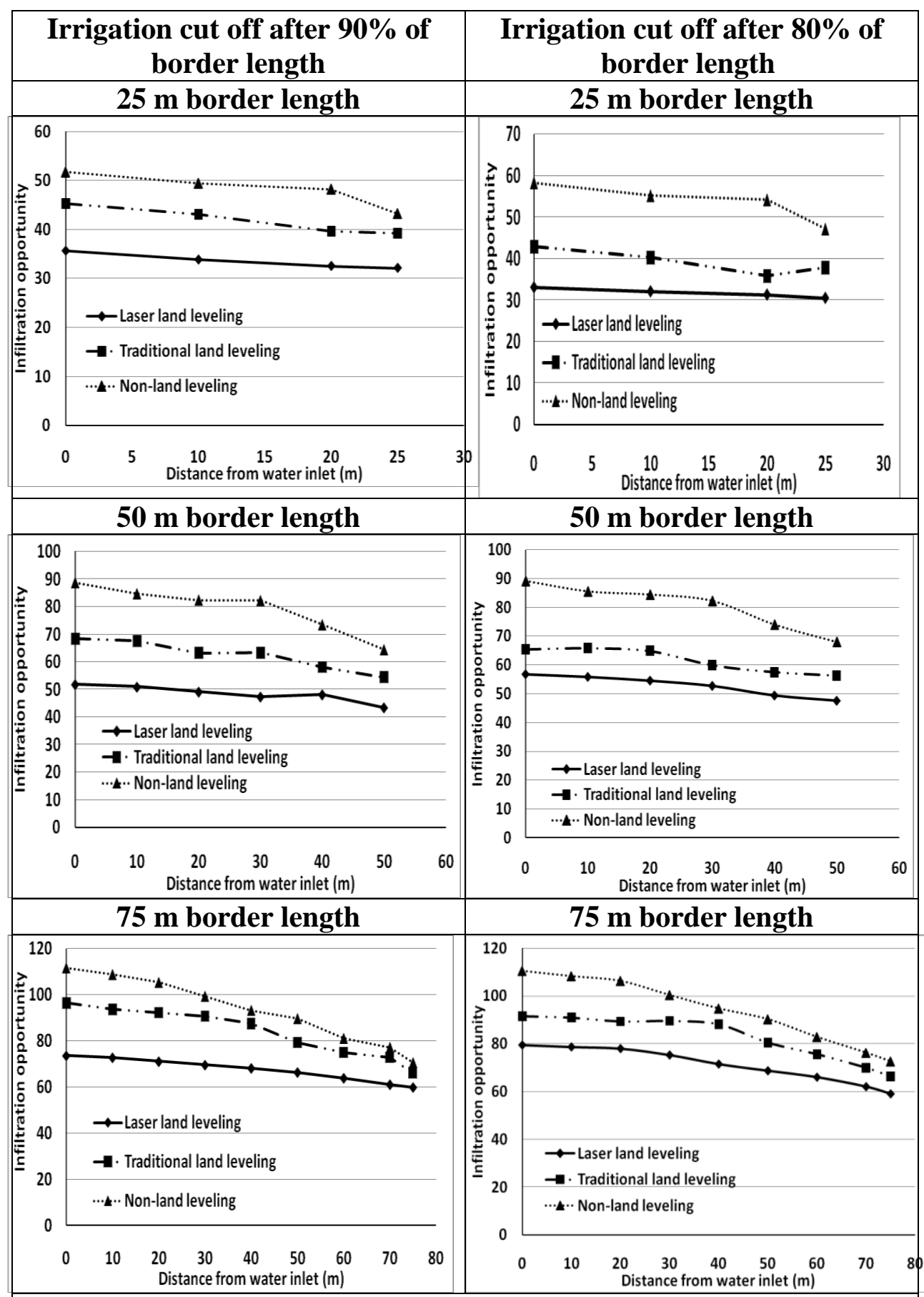

Fig.(13): Infiltration opportunity time under $25 \mathrm{~cm}$ tillage depth and different treatments in calcareous soil 


\section{الملخص العربي}

\section{حركة المياه في الأراضي الجيرية تحت الحرث والتسوية وشرائح الرى}

السادت ابراهيم علي عبد العالi

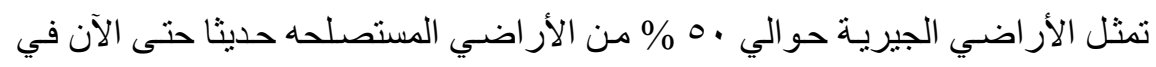

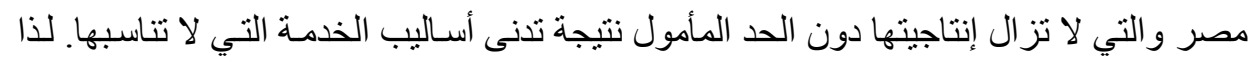

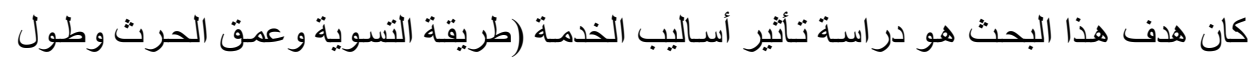
شـر ائح الـرى) على الخـو اص الطبيعيـة للتربـة وحركـة الميـاه فى الأر اضــي الجيريـة لتعظيم الاستفادة من مباه الري.

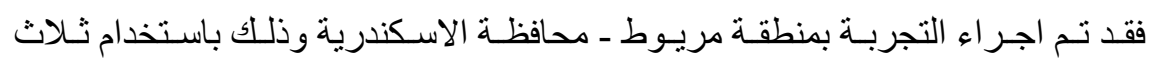
معساملات للتسـوية و هـي التسـوية بـالليزر و التسـوية التقليديـة وبـدون تسـوية، وثثلاثـة أعمـاق

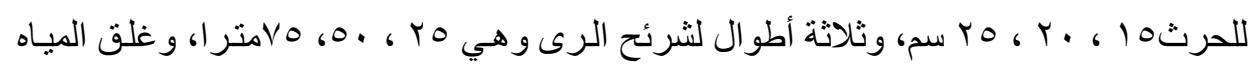

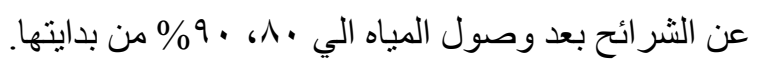
وقد أمكن استخلاص النتائج التالية:

- وجد ان الكثافة الظاهرية ومقاومة التربة للاختراق تزداد فى الأراضى الجيرية باستخدام

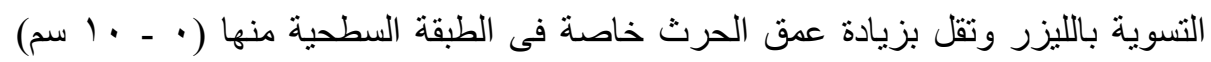

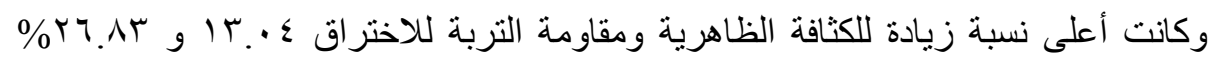
على الترتيب عند التسوية بالليزر مع عمق حرث 10 أنم.

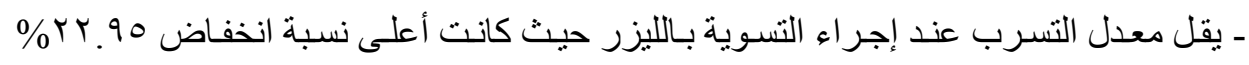

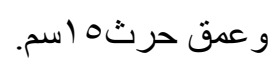

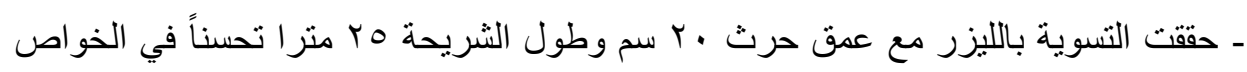
الطبيعية للتربة وحركة المياه بها.

i أستاذ الهزدة الزراعية المساعد ـ قسم الهندسة الزراعية ـ كلية الزراعة ـ جامعة الزقازيق 